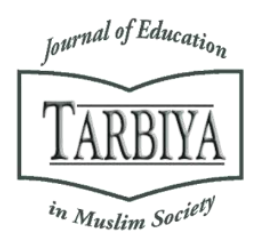

Available online at TARBIYA: Journal of Education in Muslim Society Website:

http://journal.uinjkt.ac.id/index.php/tarbiya

TARBIYA: Journal of Education in Muslim Society, 6(2), 2019, 220-232

\title{
RELIGIOUS SECTARIANISM DESTROYING THE PEACEFUL IMAGE OF ISLAMIC COUNTRY: A CASE STUDY OF PAKISTAN
}

\author{
Muhammad Hamza', Samia Shams ${ }^{2}$ \\ ${ }^{1}$ Department of Management Studies, Virtual University of Pakistan, Pakistan \\ ${ }^{2}$ Business Administration, NCBA\&E, Lahore, Pakistan \\ E-mail: ameerhamza4445@gmail.com
}

Received:27 $7^{\text {th }}$ Oktober 2019; Revised: $28^{\text {th }}$ November 2019; Accepted: $28^{\text {th }}$ December 2019

\begin{abstract}
Religious harmony considers good for the development of any sovereign country, in which different schools of thoughts/sects play a vital role in society. Some namely scholars in different religious sects of Islam such as Sunni (Wahhabi, Deobandi, Ahl-e-Hadith and Baralvi) Shia are involving in supporting of sectarianism violence and also destroying the peaceful image of the country from last three decades. Sectarianism conflict is a big hindrance for the development of religious affairs and economy of the country. This study will highlight the role of religious sects and effects on the natives of the country. How sectarianisms destroyed the peaceful image of Pakistan in the world under the shadows of Islam. This cross sectional study of Three month duration which conducted from the present and pass out students of modern educational institutions and religious Madrassa from Punjab, Khyber Pakhtunkhawa, Sindh, Baluchistan and Azad Jammu \& Kashmir. For better results of the study, 400 respondents (male and female) selected and analyzed data. As per survey results and primary findings, sectarianism is a bad curse which destroyed the gross-roots of the natives of country religiously, economically and politically for last many years.
\end{abstract}

Keywords: sects; political parties; foreign countries; militant organization

\section{Abstrak}

Kerukunan umat beragama dianggap baik bagi perkembangan negara berdaulat, berbagai aliran pemikiran/sekte berperan penting dalam kehidupan masyarakat. Sehingga ada beberapa cendikiawan yang berbeda seperti Sunni (Wahhabi, Deobandi, Ahl-e-Hadits dan Baralvi) Syiah terlibat dalam mendukung kekerasan sektarianisme yang menghancurkan citra damai negara dari tiga dekade terakhir. Konflik sektarianisme adalah penghalang besar bagi perkembangan urusan agama dan ekonomi negara. Studi ini akan menyoroti peran sekte dan efek agama pada penduduk asli negara itu. Bagaimana sektarianisme menghancurkan citra damai Pakistan di dunia di bawah bayang-bayang Islam. Studi cross sectional ini berdurasi tiga bulan yang dilakukan dari sekarang dan lulus siswa dari lembaga pendidikan modern dan madrasah agama dari Punjab, Khyber Pakhtunkhawa, Sindh, Baluchistan dan Azad Jammu \& Kashmir. Untuk hasil penelitian yang lebih baik, 400 responden (pria dan wanita) memilih dan menganalisis data. Sesuai hasil survei dan temuan utama, sektarianisme adalah kutukan buruk yang menghancurkan akarakar kasar penduduk asli negara secara agama, ekonomi dan politik selama beberapa tahun terakhir.

Kata kunci: sekte; partai-partai politik; negara asing; organisasi militan

How to Cite: Hamza, M., Shams, S. (2019). Religious Sectarianism Destroying the Peaceful Image of Islamic Country: A Case Study of Pakistan. TARBIYA: Journal of Education in Muslim Society, 6(2), 220-232. doi:10.15408/tjems.v6i2.14961.

Permalink/DOI: http://dx.doi.org/10.15408/tjems.v6i2.14961 


\section{Introduction}

The term sect used in religion to designate a group of people which use their followers for completion of religious affairs. It is also used in the sociology of religion to designate a particular kind of religious group (Nadeem, 2014). Usually, a sect is a group of people who hold certain divergent opinions from those of others who are accounted to be of the same religion. Normally this word is used for a "separately organized religious group having its typical name and its own holy places of worship". Islam is a peaceful religion and spreading rapidly than other religions in the world. A huge population of other religions has been accepting the message of Islam day by day since the nineteen century. The preachers and scholars of Islam motivate people and guide them about the values of Islam and its effects on daily life hereafter. Islam teaches their followers for equal rights without cast creed, races difference and neglect classification of rich and poor.

The preachers of other religions make strive and trying to stop this thing without using any direct force. Therefore, their leaders/scholars took start to interfere in religion Islam. For the completion of this task, they utilized political leaders, scholars and preachers and also used them for own purposes. They motivated on extremism and provided them financial assistance in the form of wages Jihad against non-Muslim. The Muslim scholars have divided Islam in different sects for their own interests under the agenda of non-Muslims and foreigners. United States (U.S) used Zia-ul-Haq in Afghanistan against the United Soviet Sovereign Republics (USSR) under the shadow of wage jihad. Zia-ulHaq promoted Wahhabi culture and introduced Pakistan as an Islamization country in the world. Later on, this decision proved the blackish decision in the history of Pakistan. After USSR war, numerous militant/sectarianism organizations evaluated in different sects such as
Lashkar-e-Jhangvi (LeJ), Sipah-e-Sahaba Pakistan (SSP), Lashkar-e-Taiba (LeT) and Sipah-eMohammadi Pakistan (SMP) in across the country. These militant organizations have worked in the country under the shadows of religion sectarianism and spoiled the innocents' people, especially the young generation. After the 9/11 scenario, these sectarianism organizations destroyed much the religion of Islam and Pakistan in the manipulation of innocents people against military forces and crowd place under the shadows of Jihad. In these strives, a huge population of the country affected, in which many of them killed and injured during violence and conflicts. They are working for the agenda of foreign countries. Saudi Arab supports Deobandi and Wahhabi sects for the promotion of real values of Islam and political support against Iran. On the other hand, Iran promotes Shia sects for increasing their political interests against the Saudi government and protection of the Shia community in the country.

Political parties of the country such as Pakistan Muslim League Nawaz (PML-N), Pakistan People's Party (PPP), Jammat-e-Islami (JI), Muthida Majlas-e-Amal (MMA), Awami National Party (ANP) and Jamiat Ulema-e-Islam (JUI) supported sectarianism groups for increase public unrest and used them against opponent elected governments. Pervez Musharraf, former president of Pakistan, banned on sectarianism organizations and froze their assists. He started crack-down and order for military action against them for public benefit. However, the leaders of political parties and the government failed to stop sectarianism conflicts in the country. These State actors destroyed the peace message of Islam in implementation of awful policies and also created the biggest hurdle in the way of development for the country. 


\section{Evaluation of Sectarianism}

The first political disparity evaluated in the Muslim Ummah was about in the period of the caliph Abu Bakar (R.A) after the death of Prophet Muhammad, Peace Be Upon Him (P.B.U.H) in 632. The Arab tribes who were follower him, split over that who should inherit both political and religious office of the Muslim Ummah. A group of famous early followers of Muhammad (P.B.U.H) nominated Abu Bakr (R.A), to be the first caliph. This decision led to the dissatisfaction a group at that time who favors Hazrat Ali (R.A) for the office of Caliph. The same controversy continued over the second caliph Hazrat Umar-e-Farooq and the third Hazrat Usman-e-Ghani as well. When the battles of Jamal and Safeen were fought, these differences turned into religious. These dispute led to the emergence of different sects in Muslim history. For example, some historians, Kharijites are considered to the first sect. Kharijites were the supporters of Hazrat Ali until the battle of Saeen (John, 2015). But they withdrew their support to Hazrat Ali by saying that any human being has no right to become a judge in the matters of religion.

\section{Evaluation of Sectarianism in Pakistan}

Pakistan is the first country in the world which is established to the name of religion Islam. More than 90 per cent population of the country belongs to the Muslim religion. Furthermore, Islam has divided into different Sunni-Shia sects. But the followers/believers of this religion destroyed the objective of Islam and Pakistan, which made a big cause of separation from Hindus. Since its evaluation, different religious sects controlled over the mentality of the natives. Gradually, some followers of these sects interlinked with sectarianism and militant organizations in the 1980s. These organizations used these people as power and utilized them in conflicts. In Pakistan, Sectarianism has made the most dangerous factor in religious, social, political and security order activities. These factors increased sectarian violence, and internal security situation becomes worsen (Christine, 2015). It is true that religious segregation plays an important role in sectarian violence, but the unstable circumstance of the country, political climate, cultural climate, and economic gains are the major factors that lead to religious sectarianism conflicts.

\section{Sectarianism Conflict}

All Sunni and Shia sectarianism organizations are creating instability on State issues and create a bad image in promoting religious affairs on the national and international level. These groups have their own Madrassa, religious curriculum and preachers. They have different believes, religious preaching style (prayer) Mosques, Imam Bargah and Hajj. Moreover, each sect attracts their preachers/followers from different social strategies according to region. Deoband sect parties, Jamiat Ulema-e-Islam, has divided into three functions like as Jamiat Ulema-e-Pakistan (JUP), Sipah-e-Sahaba Pakistan (SSP) and Lashkar-e-Jhangvi (LJ). In which LeJ is commonly known as an anti-Shia party since its evaluation. Religious sectarianism is a principle source of militant and terrorist activities in Pakistan (Asia Report, 2005).

Sunni sect can be divided into four major categories like as Baralvi, Deobandi, Ahle Hadith and Wahhabi. Jammat-e-Islami is a Sunni political party which is working before the Independence of Pakistan in the 1940s. The Ahle Hadith is a small sect from the inspiration of Wahhabi sponsored by Saudi Arab. But they do follow the principles of Sunni Schools of thought and its jurisprudence. Deobandi and Baralvi both sects are close links with different attitudes on Sufi orders. They believed that Islam arrives at the Subcontinent/Pakistan from the efforts of 
Sufism. On the other hand, Ahle-e-Hadith and Wahhabi reject this belief and condemned on Sufi shrines and culture. Deobandi and Baralvi conflict was raise on several issues regarding Sufism and sharine after in the 1990s.

The religious sectarianism was started by both Shia and Sunni sects in 1985. The conflict between Deobandi and Shia extremism has been principally responsible for a terrorist organization which was active from last three decades. The Shia community has evaluated as a pressure group, political wing and religious organization under the influence of Iran. The main Shia party was Tahrik-i-Islami and called as Tahrik-e-Jafaria Pakistan. It was banned in 2002. The Sipah-eMohammadi Pakistan (SMP) is a Shia militant organization which creating instability against Deobandi and Wahhabi. The Sunni-Shia, Baralvi-Deobandi-Wahhabi Ulema conflicts increased day by day and have woken the roots of the country for own interests. In these SunniShia conflicts, 3000 above people have been killed from 1995 to 2017 (Asia Report, 2005).

\section{Role of Zia-ul-Haque in Support of Sectarianism}

Zia ul-Haque encouraged and promoted religious sectarianism, especially Deobandi, Ahle Hadith, Wahhabi, and the main beneficiaries of these organizations was Jammat-e-Islami (JI). Islami Jamiat Talaba (IJT) is working as a pressure group of JI in public and private colleges and universities across the country. Zia government-supported Deobandi Madras for support of Jihadi activities in Afghanistan. He used these sects to control the activities of Shia community which supported by Pakistan People's Party under the instructions of Iran. Zulifqar Ali Bhutto supported Shia on religious sectarianism issue and sanctioned aids, grants etc., and issued orders for their protection. Thus, after the introduction of $\mathrm{Zia}$ Islamization policies, the Shia mobilized them and marched toward Islamabad to show the strength and demand their rights. But Zia rejected their demands strictly. But after the death of Zia, Shia community divided and started to support different political parties such as Pakistan People's Party (PPP), Pakistan Muslim League Nawaz (PML-N) and Muthida Majlas-e-Amal (MMA) etc.

\section{Role of Musharraf against Sectarianism}

After the $9 / 11$ incident, the Pervez Musharraf government tried much to control militancy and terrorism but not successful completely. He took banned on militancy and sectarianism in 2002. He started military operations in Federal Administered Tribal Area (FATA) against al-Qaeda, Taliban and their facilitators. It assesses the performance in curbing religious extremism of its domestic and external policies and implementation of its foreign commitments (2005). He tried to control LalMasjid seminary, but the results were not successful. He ordered military forces for military action on Lal-Masjid in Federal City of Pakistan Islamabad in 2007. As resulted in 150 above students, children, teacher and military forces personnel's were martyred. In this operation, numerous females were kidnapped, and state authority failed to search them. Some religious sectarianism organizations protested against his orders. Several students of Lal-Masjid interlinked with militant organizations such as Tahrik-eTaliban Pakistan, Lashkar-e-Jhangvi etc. These militant organizations spoiled the teenage students in using them in anti-state activities.

\section{Foreign Support of Religious Sectarianism}

Iran and Saudi Arab created big hindrance in supporting religious sectarianism for their own interests in Pakistan. They created instability and religious conflicts between Sunni-Shia sects. Several religious, political parties of the country, especially JI and JUI, provided financial 
assistance, weapons and trained the people to fight in Afghanistan. On the other hands, Shia's want to make a conspiracy against the state of Pakistan from the support of Iran, India and Jews. Sipah Sahaba Pakistan (SSP) was formed in 1985 with the support of Saudi Arab against Shia movement, so that influence of Iran could be reduced in Pakistan. After the 9/11 incident, Russia and Indian intelligence agencies provided financial assistance to different sectarianism groups to fight against NATO security forces and Pakistan military forces. These foreign countries such as Iran, Afghanistan, Israel and India tried to prove Pakistan as a terrorist country in the world, but all efforts failed due to a successful strategy of the Pakistan military forces.

\section{Religious Affairs as Per Quran}

The holy Quran in Sura Al-Hujarat (The Inner Apartments) says that the believers are but a single brotherhood: so, make peace and reconciliation between your two (contending) brothers; and fear of Allah, so that you may receive mercy lack of tolerance and the sectarian divide are a misfortune for a society (Asma, 2017). It is against the teachings of Islam. Islam basically stands for peace. Extremism and sectarianism was not a major issue in Pakistan before the 1980s. For the last three decades, sectarianism is damaging the state as well as the society of Pakistan. It has become a constant threat to the stability of the country. Its negative impacts are damaging the society on many fronts, i.e. psychologically, economically, politically and socially. The most unfortunate thing is that some sects involved in violence, claims that they are serving the religion. They target the top leadership of opposing sect, religious scholars and innocent worshippers and claim that they are serving the religion. It has negatively impacted the soft image of Islam.

\section{Value of Jihad as Quran Verses}

The Quran gives directions point by point and implements rules with respect to lead of war: who is to battle and who is exempted (48:17, 9:91) when dangers must stop (2:192), how detainees ought to be dealt with them. Allah emphasis in Quran to protect the people in a war zone who requested for protection, children, women and old people. It would be illegal to kill non-combatants and in addition ladies and kids and priests and rahibbis, who was given the guarantee of insusceptibility except if they had participated in the battling (L Esposito, 2015). The Quran states that there is no impulse in religion" (2:256) yet rather to spread its upright request with the goal that numbness and unbelief could be supplanted by only social orders all through the world. The religious avocation made for a jihad to proliferate the confidence is associated with Islam's widespread mission to get the message out of God and the simple rule of God's will for all humankind: "So let there be a body among you who may call to the great, charge what is regarded and prohibit what is abominable".

The Quranic importance of jihad alludes to the commitment occupant on all Muslims to battle or apply (jihad) oneself, to take after and understand God's will: to have an ethical existence, to battle unworthiness and mistreatment, change and make an equitable society and, if vital, participate in outfitted battle to protect one's locale and religion. Quranic sections alluding to jihad as equipped battle falls into two general classes: guarded, those that accentuate battling against hostility, and hostile or expansionist, a broader charge to battle against all unbelievers and spread the message and open request of Islam. Muslims all through the ages have talked about, discussed and differ about the importance of jihad, it's guarded and expansionist, authentic and ill-conceived frames (8; 9 p. 119). The Quran does not charge or 
support ill-conceived brutality and psychological warfare. Religious researchers dissolved before Meccan Quranic verses for the more activist versus uncovered in Medina and after those rulers utilized these verses in Islamic law to honest to goodness their military jihads of success and magnificent extension for the sake of guarding and spreading Islam. Be that as it may, suicide shelling turned into an across the board strategy, utilized by Sunni and Shia civilian armies, in partisan clashes overpower (Esposito, 2015).

\section{Method}

In this research, study Qualitative and Quantitative methods used for the analysis of the data. A research survey conducted in different regions in seeking the real picture of affected residents. The deductive approach has been used. Survey method has opted as part of a strategy in this research. For better results, SPSS16 software was used to the static point of view. Exclusion criteria: Respondents below16 years of age in both genders, below graduation in modern education. In religious institutional respondents was necessary for Hafiz-e-Quran along with middle education and others were exclude from the study.

\section{Study Population}

Research data was collected from Punjab, Khyber Pakhtunkhawa, Baluchistan, Sind Hyderabad and Muzaffarabad Azad Jammu and Kashmir and online Google form other countries of the world by using of email address. Research is self-administered by the researcher to the respondents of current and past students of Madrassa, modern educational institutions.

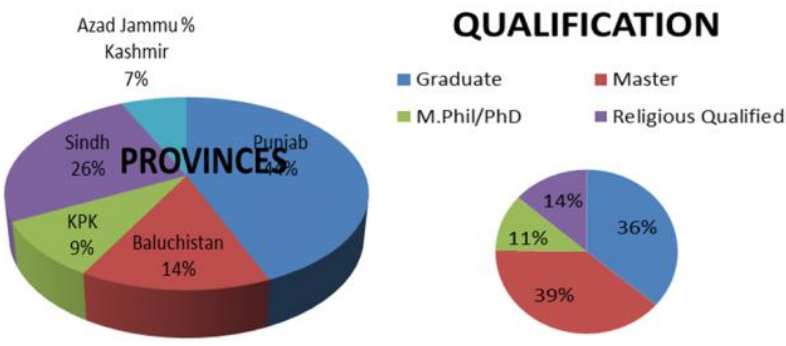

Figure 1. Study Population

\section{Sample Size and Duration}

In this study, 600 Questionnaire forms were distributed, and 200 email addresses were used for the collection of data. In the above questionnaire, 250 survey forms were excluded if less than age 16 years and under graduation.

\section{Demographic data}

In this study, 400 respondents (272 Male and 128 Female) participated. In which 231 participated from urban, and 169 belonged to rural areas.

\section{GENDER}

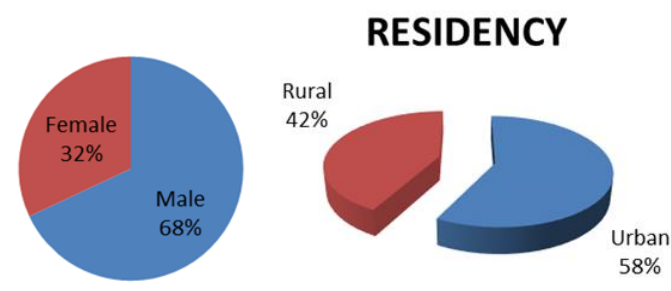

Figure 2. Demographic data

\section{Research Instrument}

In this research, the questionnaire has been used as a research instrument. Research Performa was formulated in five variables "Strongly Agree, Agree, Do not Know/Neutral, Disagree and Strongly Disagree" as per choice. Questions were selected according to the parameters of the study. All the domains used in the study, i.e. questionnaire have vital importance in the Past, Present and the Future aspects of this study. 


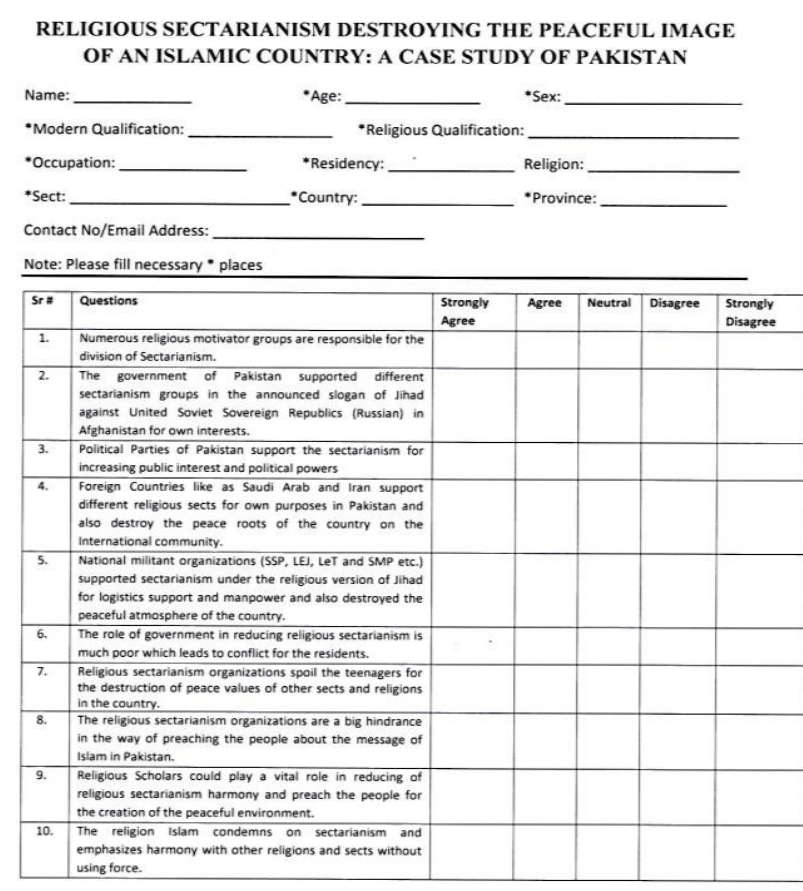

Figure 3. Survey Questionnaire Form

\section{Results and Discussion}

As per figure 4. Islam condemned on the desperation of religious affairs not only for Islam but also acted upon the obedience of other religions in the world. Islam is a peaceful religion in the world, like other religions in the Universe. But some namely scholars destroyed the peace roots of Islam for own purposes. They divided the religion of Islam in different sects (SunniWahhabi, Deobandi and Shia, etc.) and also started to call them Kafir. In this motive government of Pakistan is equally responsible for this scenario. Different political parties, different religious schools of thoughts for own purposes. Some foreign countries used religious people under the shadows of Jihad for their own purpose. As results, terrorism and militancy increased in Pakistan. The local militant's organizations like as SSP, LeJ, TTP and TNSM increased the militants' strength from Deoband and Wahhabi religious Madrassa and used them against anti-state activities. The role of religious scholars and government officials is not satisfactory as per figure 4 in the creation of a pleasant atmosphere.

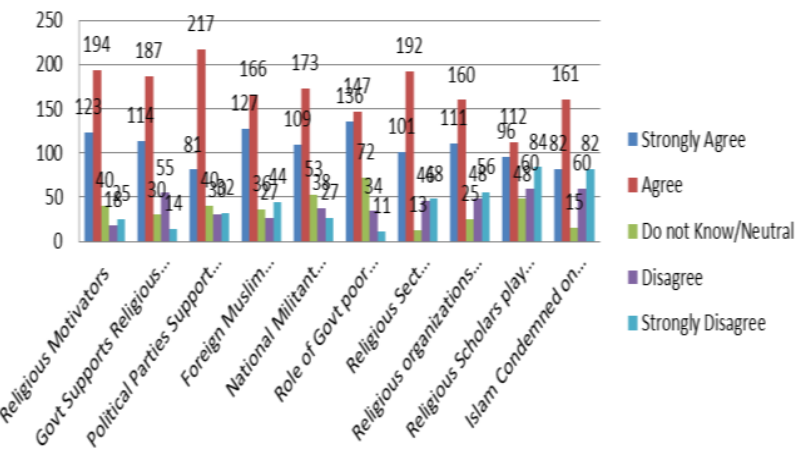

Figure 4. Results survey data

\section{Discussion}

Religious scholars and motivators of different sects like as Wahhabi, Deobandi, Baralvi and Shia preach the people for own sects. For the completion of this purpose, they motivate them about the values of their own sect. They are also preaching them; their sect leads to paradise, and all other sects shall lead to hell. Their leaders forget the values and versatility of religion, Islam. Allah says many times in Quran about humanity and rights of people without differentiation of sects and religions. Some of namely scholars/Khatib/Imam Masjid has insufficient knowledge about religion. These people interact with the innocent's with their sweet voices and different styles. They create hated against other sects to show that their sects are holy as per religion Islam. These religious sects have different schools of thoughts and religious predecessor like as Ghous-ul- Azam, Maulana Ashraf Thanvi, Shah Waliullah Dehalvi and Khameeni etc. Apart from Sunni Islam, much influences of Sufism and Wahhabi do not like Sufism and make another threat to the nation for religious sectarian conflicts (Bashir Ahmad, 2015). They put blame other sects and some-times issues rose on conflicts. Approximately 3000 above innocents' people have been killed in religious sectarianism from 1985 to 2017. A number of top-level religious scholars and motivators have been killed like 
Haqnawaz Jhangvi, Riaz Basra, Masood Azhar Zia-ur-Rehman Farooqi and Maulana Sami ul Haq etc. (Nadeem, 2014). Pakistan is one of those countries in the world where religious extremism increasing with the passage of time.

Comparative to the previous studies, in correspondence to Figure-VII, the majority agreed that the religious motivator groups are responsible for the division of Sectarianism. Every government of a respective country follows the laws and abides by the rules of religion and ethics, and hence many of the people have agreed to the point that the state of Pakistan has always encouraged different sectarianism groups in the announced slogan of Jihad against United Soviet Sovereign Republics (Russian) in Afghanistan for its own interests. Politics is always an essential component to rule or be ruled by powers implemented for running state affairs. Many have agreed to this point that the Political parties of Pakistan have always supported sectarianism for increasing public interest and gain political powers. Every Islamic country represents its own sect. Sunnis in majority reside in Saudi Arabia, whereas the majority population of Shia is home to Iran rather than other parts of the Islamic Sub-Continent. The majority have agreed to this point that every sect from a particular major country support their own sect brethren in Pakistan and also destroy the peace roots of the country on the international community. The local militant's organizations like as SSP, LeJ, TTP and TNSM increased the militants' strength from Deoband and Wahhabi religious Madrassa and used them against anti-state activities for disrupting the peaceful atmosphere of the country due to increase manpower and logistics support. The state or government is always selected by its own nation, and they expect a harmonizing relationship with every sect forming positive reinforcements between all the respected religious scholars; however, the role of government officials and different religious sectarianism organizations to date is not satisfactory to create a peaceful environment thus causing conflicts within sects especially spoiling the adolescents. Islam is the religion of love and peace with most of the agreement comes with the fact that religious scholars can play a pivotal role to end the religious sectarianism hatred thus creating a peaceful atmosphere and promoting a harmonious relationship with other religions and sects without using force.

Jamiat Ulema-e-Islam, Majlas-e-Ahrar-eIslam, Sipah-e-Sahaba Pakistan, Tahrik-eTaliban Pakistan and Lashkar-e-Jhangvi are the political, religious and militant wings of Deoband School of thoughts. They have own Madrassa which often uses for the facilitation of militancy in different regions in all provinces of the country, but Federal Administered Tribal Area is the hub areas of militancy. Sectarianism has to turn out to be a vide source of violence that largely via acts of terrorism and militancy. This thing largely becomes an urban incident. Religious Madrassa and other seminars are these widest nurseries of theses sectarian religious soldiers (Kazmi, 2006). Majority of these madrassas are running Deobandi sect, and they prepare students for Jihad/fight against nonMuslim and also provide them financial assistance in different conflict zones like as Jammu and Kashmir, Palestine and Chechnya etc. On the other hand, only $3 \%$ of Madrassa is running Shia sect across the country. The conflict between Sunni-Shia sects is much dangerous for the development of the country. The Red mosque episode in Islamabad is a reminder of how fragile Pakistani society is while dealing with a group of religious extremists, who want to impose their parochial beliefs and way of life on others (Moonis, 2008). The religious scholars of Lal-Masjid created hate with other sects. They spoiled their followers against other sects like Shia and Baralvi-Deobandi. 
Numerous political parties supported different religious sectarianism for their own interests. Pakistan People's Party supported Shia sect to increase their political power; on the other hand, Pakistan Muslim League-Nawaz (PML-N) supported Sunni sects (Wahhabi, Deobandi and Ahl-e-Hadith). But while Muthida Majlas-eAmal (MMA) and Jammat-e-Islami (JI) provided assistance to Deobandi sect for increase political interests in across the country. The Pakistan nation faces different local and foreign challenges related to sectarianism violence, security problems, religious extremism and political violence on different forums (Zahid Shahab Ahmed, 2016). The namely religious organization Jamaat-e-Islami have hijacked during this period, and the country nations saw bloody Sunni-Shia sectarian conflicts in the forms of Taliban's attacks and sectarian conflicts (Ishtiaq Ahmad, 2009). General Zia has strong relations with Jammat-e-Islami and other Sunni organizations in seeking of Jihadi activities (Joy Aoun, 2012). These political parties provided financial assistance for the construction of new Madrassa and born other expenditures without check and balance on students and teachers for their militant's activities. The students of these madrassas serve as political wings for these political parties. The political workers use their followers in elections, political instability and other own purposes. The Sunni sect (Wahhabi, Deobandi and Ahl-e-Hadith) supported Pakistan Muslim League Nawaz against Pervez Musharraf on the issue of Judicial System Pakistan. Numerous students of different Madrassa from Lahore, along with teachers participated in the protest. Numerous Shia followers protested in the rally and condemned the death of Benazir Bhutto in 2007. The students of Minhaj University of Lahore participated in the political rally under the leadership of Dr Tahir-ul-Qadiri in Islamabad 2014. These sects challenged the writ of State and destroyed the machinery of the government several times. During these protests, the government has born billion rupees loss. A huge number of students and other protesters have also been killed and injured in the conflicts last many decades during these protest.

Many Arab Gulf countries support Sunni sect, and Shia is the loyalists of Irani nation (Geneive Abdo, 2013). These foreign countries like as Saudi Arab, United Arab Emirates, Kuwait and Iran support different religious sects to increase their interests in the country. Saudi Arab and other Middle Eastern countries support Deobandi and Wahhabi sects against Baralvi and Shia sect. They built pressure on several governments at different times against the government of Iran. They provided financial assistance and trained people in Baluchistan and Sindh. They attacked people who travel to Iran and Iraq via road (Baluchistan) several times. In these consequences, thousands of innocents' people have been killed in sectarianism conflict. On the other hand, Iran supports Shia community and provide them with assistance. They want to build relations for the betterment of their community and country. The government of Pakistan tried much to solve the issue between Saudi Arab and Iran. But the government of Iran is playing under the hands of India. The Indian government has made a huge investment in Iran such as Chahbihar Port, build different hospitals and military relationship between both countries. These sects have religious links with Arab and Iran like Hajj and other holy places in Saudi Arab and Iran. These countries use the people of different sects against each other and have a big hurdle in sect pluralism in the country. The natives of the country have been divided just for the implementation of supremacy in different sects. Foreign governments provide them with funding for their extremist's activities.

Numerous local militant organizations such as Sipah-e-Sahaba Pakistan (SSP), Lashkar-eJhangvi (LeJ) and Sipah-e-Mohammadi Pakistan 
(SMP) supported religious sectarianism in different circumstances. Some local traders of different provinces of the country provide funding to sectarian Sunni organizations such as Sipah-e Sahaba (SSP) and Lashkar-e Jhangvi (LJ) (Tahir Kamran). The Sipah-e-Sahab and Lashkar-e-Jhangvi created big hurdles against Shia, and religious clashes such as Munazara and sectarian conflicts increased day by day (William Racimora, 2013). They provided financial assistance to religious scholars and used them for their own interests. This religious sectarianism Madrassa provided manpower to militant organizations. These militant organizations use innocents' students/teenager in a bomb blast and suicide attacks in crowd places, and security forces personnel's in across the country. This rehearsal increased after the 9/11 incident, and the government took serious note on student activities in different Madrassa. A large number of innocent people killed and injured in LEJ and SMP conflict in Jhang and other areas of Punjab. The suicide bomb blast at the Bari Imam shrine near the diplomatic quarter of the Pakistani capital, on May 27 which resulted in the deaths of at least 20 Shi'a worshippers (most likely carried out by a LeJ suicide bomber) underscores the intractable intensity and lethality of Pakistan's sectarian conflict. In 2002, more than 30 Lashkar-e-Jhangvi militants were killed in numerous shootouts that resulted in the deaths of senior leaders. These included Riaz Basra, who was killed along with three associates near Mailsi in Multan on May 2014, and LeJ chief Asif Ramzi, who was slain with six accomplices near Allahwala Town in Karachi. The slayings of Basra and Ramzi dealt a severe blow to the foundation of LeJ and its mother organization, Sipah-e-Sahaba Pakistan. Riaz Basra is believed to have been involved in more than 300 sectarian attacks; it is also believed that he personally directed all attacks on Iranian interests in Pakistan. Before his elevation to the commanding heights of LeJ's leadership, Basra was the commander of the Khalid bin Walid unit of the Afghan Mujahideen in Afghanistan (Animesh Roul, 2005).

Religious Scholars of different sects manipulate their followers, particularly teenager in sectarianism conflict. They preach their followers specifically about religion, own sect and also call other sects shall lead to hell. They do not talk about the universality of religion and humanity. They do not guide the people about the good relationship with other people without religious dimensions. Shia School of thoughts is different from Sunni School of thoughts. They believe that the Prophet Mohammad (P.B.U.H) has nominated last Caliph to Hazrat Ali (A.S) in his last Khutba, so Hazrat Ali (A.S) was the only person who has a religious influence to succeed Mohammad. The Shia also believes that Ehl-eBait was most respected and honourable than any other people in Sahaba (Asma, 2017). On the other hand, Sunni School of thought believes that the method of choosing leader/Sardar is mentioned or explained in the Quran is a consensus of Muslim Ummah. So they follow the Khulafa-e-Rashideen, i.e. first caliph is Hazrat Abu-Bakar (R.A), second Hazrat Umar (R.A), Third Hazrat Usman Ghani (R.A) and fourth was Hazrat Ali (R.A). This was the basic starting of Sunni-Shia conflict (Asma, 2017). A number of Shia-Sunni conflicts happen just for the results of religious scholars misconceptions. Every year government put a ban on some religious preachers in holy months, particularly in Moharram-ul-Harram for the protection of sectarianism conflict. As a resulted, numerous people killed and injured in the holy months of Moharam-ul-Haram, Eid-ul-Fitar, Eid-ul-Adha and Rabi-ul-Awal etc. Thirteen people were killed in Rawalpindi from the holiday of $10^{\text {th }}$ Moharram between Shia and Ahl-e-Hadith sects in November 2013 (Baqir Sajid, 2013). These incidents created a bad image of Islam in other religions of the world. Therefore, the followers of 
other religions call Muslims as the supporters of militancy in the world, especially after the $9 / 11$ incident. But after the successful operations from security forces, the government restored the writ of the state in across the country.

Religious sectarianism threatened the businessmen and foreign investors variously. They kidnapped Chinese engineers, Journalists, doctors and politicians etc. Some of them were killed from the militants of Tahrik-e-Taliban Pakistan (TTP) and Tahrik-e-Nifaz-e-Shariat-eMohammadi (TNSM) in Swat and other areas of Khyber Pakhtunkhawa and FATA. All these things created a fearful atmosphere in the country. Mullah Fazalullah, leader of TTP and Maulana Sufi Mohammad, put a ban on modern education and fiercely closed the door of education for females in FATA and PATA under the shadow of Islam. They motivated and trained the people for war under the shadows of Jihad against NATO and security forces in Pakistan and Afghanistan. They were also destroyed the tourism industry in PATA. The provincial government suffered a billion dollars loss from 2002 to 2014. There are numerous types of sectarianism violence which have been motivated to the sectarian leaders in Pakistan. They use innocent people in targeted killing, attacks on funerals and bomb blasts on crowed places (Michael Kalin and Niloufer Siddiqui, 2014). Jhang has considered the hub of a Sunni majority but while Gilgit has the majority of Shia sects (Waseem-2010). But unfortunately, numerous incidents have happened in these areas between Sunni-Shia conflicts, in which hundreds of poor people have also been killed, kidnapped and injured.

Religious sectarianism is a big hindrance for the development of the country. Nobody ready for the make more investment Pakistan which was called conflict and violence zone in the world from the last twenty years. Not only foreign investors, but local investors also shifted their investment in foreign countries like as UAE, Saudi Arab, other Middle East countries and other Subcontinents of the world. External Debt in Pakistan increased to 91761 USD Million in the first quarter of 2018 from 88891 USD Million in the fourth quarter of 2017. External Debt in Pakistan averaged \$ 53532.35 Million from 2002 until 2018, reaching an all-time high of 91761 USD Million in the first quarter of 2018 and a record low of 33172 USD Million in the third quarter of 2004 (Trading Economies). The government has to face terrible condition in economic development. A number of sanctions are imposing from world banks, International Monarchy Fund (IMF) and others. In stable conditions, national and international investors ready to make investment and increase income. In bad circumstances like as strikes, religious conflict, curfews etc. nobody ready to more work in any country.

Islam is a peaceful religion like other religions of the world. Allah has completed the message in the form of religion Islam. The Prophet Mohammad Peace Be Upon Him (P.B.U.H) is the last prophet and Quran is the Holy book like other Taurat, Zaboor and Injeel. After the death of Mohammad P.B.U.H, new sects have been established without any jurisdictions. Currently, uncounted sects have been introduced on the name of Islam. Islam condemned sects and religious sectarianism in the world. As per religious definition and last speech of Mohammad Ali Jinnah in 1947, Muslims are a nation and Islam emphasizes on respect of humanity without any cast creed and imposes restrictions on all bad evils which create halt with other religions.

\section{Conclusion}

Religious scholars and motivators destroyed the community in supporting sectarianism for earning their bread and butter and also personal 
interests. They are responsible for thousands of innocents people for their better future. These extremist people have blackmailed the several governments from last many decades for their own interest and at the end destroyed the bright religious image of innocents people in the world. The elected governments which took the vote of the people in using of the name of religion Islam like as JI, JUI, LeT, LeJ and PML-N is also responsible for the promoting of sectarianism and hesitation for the action against their followers. These governments are also responsible for the evaluation of Sunni-Shia sectarianism. Sectarianism conflicts increased after the death of Zia-ul-Haq. He supported Deobandi and Wahhabi sects for increase influence/vote bank, Jihadi activities in the Afghan war against Russia.

Foreign countries supported sectarianism conflicts for their interests and protection of their followers. They cut out the grassroots of the country so that the Muslim community cannot make development in developed countries. On the other hand, local militant organizations like as SSP, LEJ and SMP etc. promoted sectarianism for built pressure against government's institutions. For the completion of this task, they manipulated young generation from low-income areas with the efforts of some namely Imam Masjid, Khatib and also destroyed their future in using them bomb blasts, suicide attacks against government machinery. They were also destroyed the machinery of the government socially, economically and politically. The law and order institutions played a poor role in stop/reducing sectarianism conflicts. These sectarianism organizations made big hindrance in spreading militancy. Therefore, the senior religious scholars could not highlight the real message of Islam on national and foreign people.

\section{References}

Abdo, G. (2013). “The New Sectarianism: The Arab Uprisings and the Rebirth of the Shi'a-Sunni Divide," The Saban Center of Middle East Policy at Brookings Analysis Paper Number 29, Washington, D.C: 4

Ahmad, B. (2015). The Radicalization of Pakistan and the spread of Radical Islam in Pakistan:33

Ahmad, Ishtiaq. (2009). "Reclaiming Pakistan's Pacifist Religious Creed The Middle East Institute Viewpoints: The Islamization of Pakistan 1979-2009," The Middle East Institute Washington, DC:19-20• www.mei.edu,

Ahmed, S. Z., Zeb, K. (2016). "Direct and Indirect Impacts of Terrorism on Youth in Pakistan," JRSP, 53(01):236.

Aoun, J., Danan, L., Hameed, S., Robert D. Lamb, Mixon, K. and Denise St. Peter. July (2012). "Religious Movements, Militancy, and Conflict in South Asia cases from india, pakistan, and Afghanistan," Report of the Center for Strategic International Studies program on crisis, conflict, and cooperation: 9

Baqir, S. S.. (2013). Ashura violence was staged by TTP: ISPR chief https://www.dawn. com/authors/174/baqir-sajjad-syed August 22, 2017.

Christine, C. Fair. (2015). "Explaining Support for Sectarian Terrorism in Pakistan: Piety, Maslak and Sharia," Religions, 6: 1137-1167.

Esposito, L John. (2015). "Islam and Political Violence," Religions 6: 1067-1081

Kalin, M. Siddiqui, N. (2014). "Religious Authority and the Promotion of Sectarian Tolerance in Pakistan," United States Institute of Peace Special Report Washington, DC:2. www.usip.org 
Kazmi, A. A. (2008). Pakistan: Social and Cultural Transformations in a Muslim Nation. Routledge, London and New York: 287

Mahsood, Asma K. (2017). History of Sectarianism in Pakistan: Implications for Lasting Peace, Journal of Political Sciences \& Public Affairs 5(4):2

Moonis, A. (2008). "Sectarian Conflicts in Pakistan," Pakistan Vision 9(1):17

Nadeem M. Shah. (2014). "Evolution of Sectarianism in Pakistan: A Threat to the State and Society," South Asian Studies A Research Journal of South Asian Studies 29(2):441-459
Racimora, W. (2013). "Salafist/wahhabite Financial Support to Educational, Social and Religious Institutions, European Union and Belgium,": 17

Roul, A. (2005). "Lashkar-e-Jhangvi: Sectarian Violence in Pakistan and Ties to International Terrorism," Terrorism Monitor 3(11):10

Waseem, M. (2010). "Dilemas of Pride and Pain: Sectarian Conflict and Conflict Transformation in Pakistan," Religion and Development Research Program, Working Paper 48, 2010:1 